\title{
Idiopathic inflammatory myopathies: pathogenic mechanisms of muscle weakness
}

\author{
Sree Rayavarapu ${ }^{1,2}$, William Coley ${ }^{1}$, Travis B Kinder ${ }^{1,2}$ and Kanneboyina Nagaraju ${ }^{1,2^{*}}$
}

\begin{abstract}
Idiopathic inflammatory myopathies (IIMs) are a heterogenous group of complex muscle diseases of unknown etiology. These diseases are characterized by progressive muscle weakness and damage, together with involvement of other organ systems. It is generally believed that the autoimmune response (autoreactive lymphocytes and autoantibodies) to skeletal muscle-derived antigens is responsible for the muscle fiber damage and muscle weakness in this group of disorders. Therefore, most of the current therapeutic strategies are directed at either suppressing or modifying immune cell activity. Recent studies have indicated that the underlying mechanisms that mediate muscle damage and dysfunction are multiple and complex. Emerging evidence indicates that not only autoimmune responses but also innate immune and non-immune metabolic pathways contribute to disease pathogenesis. However, the relative contributions of each of these mechanisms to disease pathogenesis are currently unknown. Here we discuss some of these complex pathways, their inter-relationships and their relation to muscle damage in myositis. Understanding the relative contributions of each of these pathways to disease pathogenesis would help us to identify suitable drug targets to alleviate muscle damage and also improve muscle weakness and quality of life for patients suffering from these debilitating muscle diseases.
\end{abstract}

Keywords: Adaptive immune, Autophagy, Cytokines, Endoplasmic reticulum stress, Innate immune, Myositis, Skeletal muscle, TLRs

\section{Review}

Idiopathic inflammatory myopathies (IIMs) include polymyositis (PM), dermatomyositis (DM) and sporadic inclusion body myositis (sIBM). The clinical features of these diseases include muscle weakness, fatigue and elevated muscle enzymes in serum, and their histological characteristics include mononuclear cell infiltration and myofiber degeneration. Immunological features include autoantibodies and autoreactive lymphocytes, with unusual over-expression of major histocompatibility complex (MHC) class I molecules on the surface of the affected myofibers. MHC molecules present processed non-self and self-antigenic peptides to T-lymphocytes and mediate immune response. The relative contribution of the autoimmune component to myositis pathogenesis is not yet known. Recent data suggest that innate immune activation

\footnotetext{
* Correspondence: knagaraju@childrensnational.org

${ }^{1}$ Research Center for Genetic Medicine, Children's National Medical Center, 111 Michigan Ave NW, Washington DC, USA

${ }^{2}$ Institute of Biomedical Sciences, The George Washington University, 2300 Eye Street, N.W., Ross 605, Washington DC, USA
}

and metabolic defects occur in the myositis muscle, suggesting a role for these pathways in disease pathogenesis [1-3]. Thus, the emerging paradigm indicates that not only innate and adaptive immune mechanisms but also intrinsic defects in skeletal muscle contribute to muscle weakness and damage in myositis. The muscle microenvironment is complex, and we propose that active interactions occur between innate, adaptive, metabolic and homeostatic pathways in muscle in these diseases.

\section{Innate immune mechanisms}

Innate immunity, also known as native immunity, is considered the early line of host defense. The innate immune system includes physical barriers (epithelial surfaces), phagocytic cells (neutrophils, macrophages, eosinophils, etc.), natural killer (NK) cells, the complement system, and cytokines. Innate immune cells primarily detect pathogen-derived antigen structures with common patterns, but not fine differences, through Toll-like receptors (TLRs) and nucleotide-binding oligomerization domain (NOD)-like receptors (NLRs), to initiate 
pro-inflammatory responses. We discuss TLRs, NLRinflammasomes, NF-kB, and cytokines in the context of muscle inflammation below. All the information discussed in this section is summarized in Figure 1.

\section{TLR signaling in skeletal muscle}

TLRs are the trans-membrane receptors expressed on immune and non-immune cells that recognize pathogens as well as self-molecules. Altogether, 13 TLRs have been identified in mice and humans. All TLRs, except TLR-3, signal via myeloid differentiation response gene 88 (MyD88), the central adaptor protein, and induce activation of the nuclear factor-kB (NF-kB) pathway, the master controller of inflammation. TLR-3 signals via Toll interleukin (IL)-1 receptor domain-containing adaptor inducing IFN- $\gamma$ (TRIF) and activates the NF-kB pathway or type I interferons (IFNs) $[1,2,14]$. TLRs recognize patterns in microorganisms termed as pathogen-associated molecular patterns (PAMPs) and endogenous ligands termed as damage associated molecular patterns (DAMPs), and initiate immune signaling $[15,16]$. PAMPs are associated with infectious agents (e.g., bacteria, fungi and viruses) whereas DAMPs are host-encoded molecules released during tissue injury, necrosis and cell death. DAMPs include nucleic acids (RNA, DNA), cytosolic heat shock proteins and nuclear high mobility group box protein 1 (HMGB1), and extracellular matrix proteins such as fibrinogen and fibronectin $[5,6,17]$. DAMPs have been

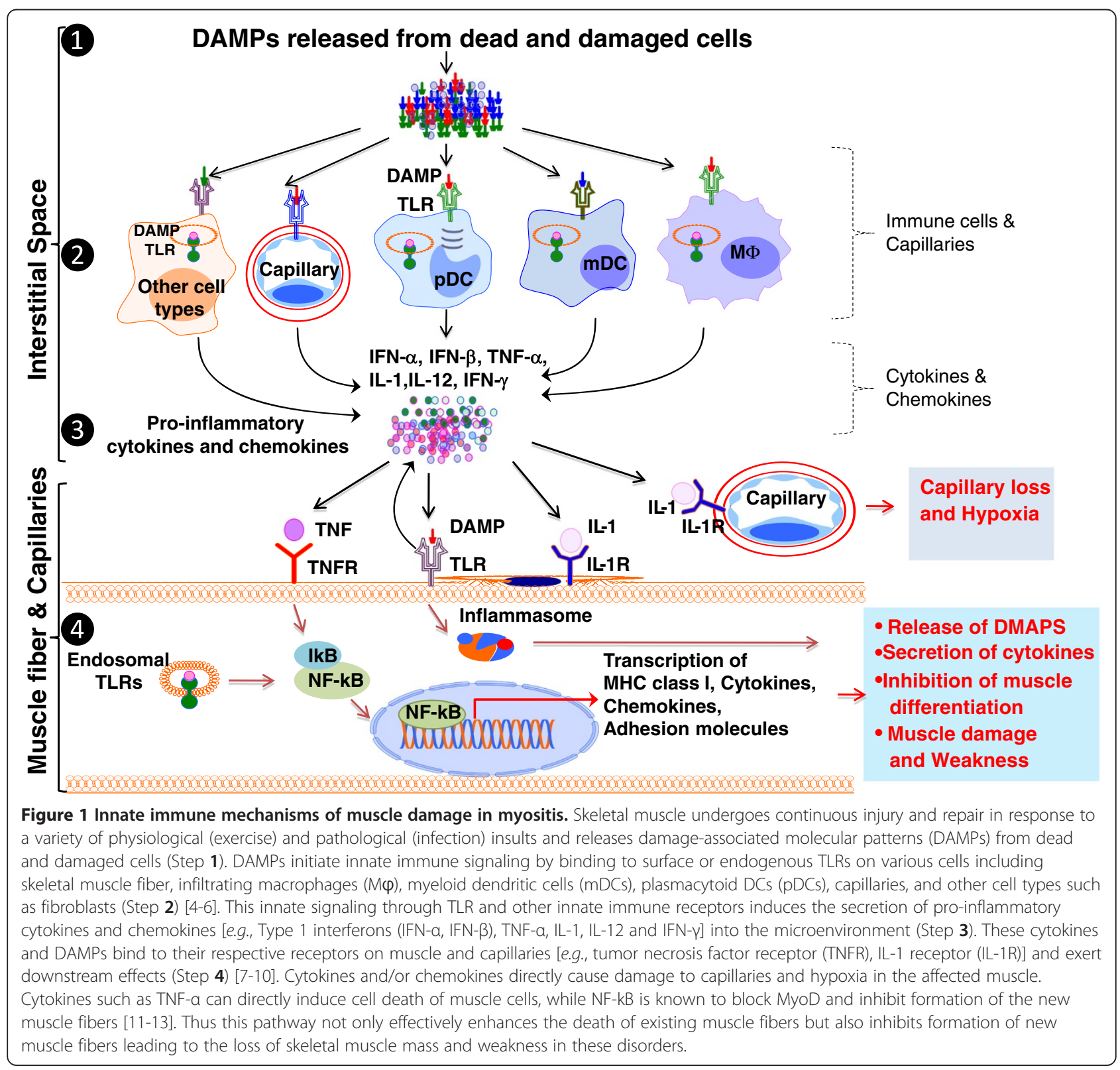


shown to induce stimulation of TLRs, resulting in immune activation and the release of cytokines, resulting in a self-sustaining autoinflammatory response that contributes to chronic inflammation in the affected tissue [18-21].

Excessive physical activity and strenuous exercise in normal individuals leads to modest elevations in serum muscle enzymes such as creatine kinase (CK), whereas myositis patients generally show a significant increase in CK, suggesting that skeletal muscle leakiness and damage occur in this disease. It is likely that some DAMPs leak from the injured skeletal muscle and engage their receptors on both skeletal muscle and immune cells, thereby perpetuating the inflammatory process. In fact, muscle biopsies of myositis patients show a significantly increased expression of TLR-2, TLR-3, TLR-4, and TLR9 in the skeletal muscle and infiltrating cells as well as the enhanced expression of cytokines such as IFN- $\gamma$, IL-4, IL-17, TNF- $\alpha$, IL- 6 and type 1 IFNs. These findings suggest that TLR receptors are engaged in the milieu of affected muscle and that the downstream genes are activated [7-9]. Further, IFN- $\beta$ and IFN- $\gamma$ are shown to enhance MHC class I expression on immature muscle precursors, suggesting that these cells may be one of the sources of local type 1 IFNs and that the regenerating fibers are potential targets of immune attack in myositis muscle [22].

More recently, one study has independently validated the enhanced expression of TLR-2, -4 , and -9 along with MyD88 mRNA transcripts, as well as enhanced protein levels in all subtypes of inflammatory myopathies [10]. The evidence for activation of TLR-4, MyD88, and the NF-kB pathway is also shown in a myosin-induced experimental autoimmune myositis (EAM) mouse model [23]. An enhanced expression of transcripts such as IFN- $\gamma$, IL-12p40, and IL-17 along with the expression of the co-stimulatory molecules CD80 and CD86 in the inflammatory milieu of the affected muscle suggests the link between innate and adaptive immune systems in the muscle microenvironment [10].

Recognition of DAMPs that activate the TLR pathway in myositis muscle is slowly emerging. For example, the histidyl-tRNA-synthetase (HRS) protein has long been associated with myositis, since it was identified as the antigen of the myositis-specific autoantibody Jo-1. Previous studies indicated that cleaved HRS serves as a chemokine by binding to CCR5 and facilitates immune cell infiltration into muscle [24]. More recent studies indicate that the $\mathrm{N}$-terminal portion of the HRS protein binds to TLRs, and immunization with HRS peptides induces both autoantibody formation and immunoglobulin class switching in mice. A loss of TLR-4 inhibits class switching, and a loss of TRIF inhibits both class switching and autoantibody secretion [25]. The exact mechanisms by which HRS cleavage and release from muscle cells occurs is unclear, but there is evidence that HRS-expressing immature muscle cells express high levels of MHC class I and therefore likely become targets of cytotoxic T-cells and granzyme B-mediated cleavage of the HRS antigen [26].

Another well-characterized DAMP that is involved in myositis pathogenesis is high mobility group box protein 1 (HMGB1). High expression of HMGB1 was detected not only in the cytoplasm of muscle, infiltrating cells and endothelial cells, but also in the interstitial space in myositis muscle suggesting its potential to engage TLRs in this milieu [4]. Exposure of HMGB1 to muscle fibers induced irreversible decrease in calcium release from the sarcoplasmic reticulum during fatigue induced by repeated tetanic contractions [27]. A recent study reported that HMGB1 induced muscle fatigue occurs via the TLR-4 pathway in muscle and that the HMGB1-TLR-4 pathway plays a role in the pathogenesis of myositis patients [4].

Taken together, these studies clearly suggest that TLRs, acting through MyD88-dependent and/or independent mechanisms, induce pro-inflammatory signals in myopathic muscle. It is likely that new advances in this field would identify additional novel DAMPs in myositis muscle. Blocking DAMP induced MyD88 dependent and independent TLR pathways using chemical and genetic methods may provide additional insights into these mechanisms. Although there are substantial gaps in our knowledge of the relationship between myositis and TLRs, and their stimulation by endogenous DAMPs, the accumulating evidence suggests that the TLRs are the connecting link that mediates interactions between innate and adaptive responses and in turn activates NF- $\mathrm{kB}$ signaling cascades in myositis.

\section{NF-kB and NLR-inflammasome activation in skeletal muscle}

The NF-kB pathway is one of the predominant regulators of a variety of essential biological processes, including inflammation. In myositis both immune and skeletal muscle cells modulate inflammation via the NF- $k B$ pathway. NF-kB is a ubiquitous transcription factor composed of a heterodimer with two subunits, p65 (Rel A)/ c-Rel/Rel B and p50. NF-kB is kept sequestered in an inactive form in the cytoplasm through an interaction with its specific inhibitor $\mathrm{IkB} \alpha$. When a stimulus is received, the upstream IkB kinase (IKK) phosphorylates $I k B \alpha$, leading to its proteosomal degradation. Free NF-kB is then translocated to the nucleus, where it regulates the expression of several pro-inflammatory genes, including TNF- $\alpha$ and IL-1 $\beta$. We have previously demonstrated that unusual overexpression of MHC class I on the muscle fibers of myositis muscle can also cause the activation of NF-kB, including the induction of ER stress 
response pathways [27]. Further evidence suggests that downstream NF-kB target genes such as intercellular adhesion molecules (ICAM) and MCP-1 are also highly up-regulated in myositis muscle. Several groups have independently validated NF-kB activation in inflammatory myopathies and its role in modulating the immune response, myogenesis and muscle repair [11-13,28].

NLR-inflammasomes are intracellular multi-protein complexes formed by the adaptor molecule apoptosisassociated speck-like protein with caspase recruiting domain (ASC), caspase- 1 , and the members of the NLR family such as NLRP1, NLRP3 and NLRC4. NLR-inflammasomes are also activated by PAMPs/DAMPs and result in secretion of the pro-inflammatory cytokines $[29,30]$. Although the process is not yet completely understood, the general consensus is that inflammasomes are activated through three signaling pathways: 1) potassium efflux, 2) generation of reactive oxygen species, and 3) production of cathepsin B [31]. More recently, our group has shown that normal primary skeletal muscle cells are capable of secreting IL-1 $\beta$ in response to combined treatment with TLR-4 ligand, lipopolysaccharide and P2X7 receptor agonist, ATP, suggesting that not only immune cells but also muscle cells can actively participate in inflammasome formation implicating skeletal muscle cells in perpetuating a pro-inflammatory environment [32].

The inflammasome pathway is connected to the TLR signaling pathway. TLR-2/4 signaling results in the synthesis of pro-IL-1 $\beta$, and inflammasomes process pro-IL-1 $\beta$ into mature IL-1 $\beta$; signaling by released extracellular ATP via P2X7 receptors (DAMP signaling) facilitates the secretion of mature IL-1 $\beta$ from the skeletal muscle cells [32]. Another recent study has characterized the mechanism of IL-1 $\beta$ secretion following respiratory syncytial virus (RSV) infection of airways [33]. This study underscored the requirement for the (TLR-2)/MyD88/NF-kB pathway prior to the activation of the inflammasomes and subsequent IL-1 $\beta$ release in the affected tissue [33]. In sum, these findings suggest a possible cross-talk between TLRs and inflammasome pathways. In myositis, the activation of inflammasomes and the subsequent release of cytokines in affected muscle have not yet been investigated; however, enhanced expression of both TLRs and IL- $1 \alpha$ and IL- $1 \beta$ in areas surrounded by inflammatory cells suggest that TLRinflammasome pathway is active in myositis muscle [34]. Therefore, it is possible that the cytokines released from the activation of inflammasome pathways can stimulate innate and adaptive immune cells and further augment the secretion of either pro-inflammatory or anti-inflammatory cytokines.

\section{Cytokines and chemokines in skeletal muscle}

Cytokines are produced by a wide variety of cells and regulate immune cell activation and infiltration in affected tissues. The most predominantly reported cytokines in myositis include pro-inflammatory cytokines such as IL$1 \alpha$, IL-1 $\beta$, TNF- $\alpha$ and transforming growth factor (TGF) $-\beta$ [34-39]. IL-1 $\alpha$ was predominantly expressed in capillary endothelial cells of PM, DM and sIBM muscle biopsies suggesting a prominent role for endothelial cells in myositis pathology $[34,35]$. Furthermore, IL- $1 \alpha$ was suggested to play a role in myofibrillar protein break down and muscle regeneration; however, these claims are yet to be proven [36]. The pathogenic role of TNF- $\alpha$ in myositis muscle was not completely understood; however, it has been hypothesized to attract immune cells by enhancing transendothelial cell trafficking in affected muscle [37]. In addition, TNF- $\alpha$ has been hypothesized to activate immune cells and induce MHC class I expression in the myositis muscle. TGF- $\beta$ was proposed to play a profibrotic role based on the correlation between its expression and connective tissue proliferation in DM muscle [39]. A plethora of studies have also reported the expression of additional cytokines and chemokines in myopathic tissues [40-50] (Table 1).

Even though a majority of the reports suggest that cytokines have a pro-inflammatory role in myositis muscle, one recent study reported a protective role for some cytokines. This study reported enhanced expression of neurotrophin receptor p75NTR on the muscle fibers of DM, PM and sIBM patients [52]. p75NTR binds to various neurotrophin-like cytokines such as NGF, BDNF, NTF3 or NTF4, and protects muscle cells against IL-1 $\beta$ induced cell death. Taken together, these studies indicate that cytokines and chemokines have different roles in the affected skeletal muscle.

\section{Adaptive immune mechanisms}

Adaptive immunity to self-antigens is induced in autoimmune diseases. This arm of immunity predominantly includes autoreactive lymphocytes and autoantibodies. Initial reports have indicated that there are differences in the lymphocyte subsets seen in PM, DM and sIBM; however, recent studies have indicated that those differences are not clear-cut and that T-cells (CD4, CD8), B-cells, macrophages, and DCs are present in all inflammatory myopathies. All the information discussed in this section is summarized in Figure 2.

\section{$T$-cells and CTL-cell-mediated injury}

$\mathrm{T}$-cells are involved in cell-mediated immune responses within the adaptive immune system. These cells express surface receptors (T-cell receptors; TCR) that recognize peptide fragments of foreign proteins when presented on the MHC molecules of antigen-presenting cells. Functional subsets of $\mathrm{T}$-cells include $\mathrm{CD} 4+\mathrm{T}$ helper cells (which recognize MHC class II-presenting peptides) and CD8+ cytotoxic T-cells (which recognize MHC class 
Table 1 Some of the important cytokines/chemokines reported in inflammatory myopathies

\begin{tabular}{|c|c|c|}
\hline Cytokines/Chemokines & Potential role & References \\
\hline IL-1a/IL1- $\beta$ & Pro-inflammatory and probably myofibrillar protein break down & {$[34-36]$} \\
\hline TNF-a & Chemo-attractant & {$[37]$} \\
\hline TGF- $\beta$ & Pro-fibrotic & [39] \\
\hline $\mid \mathrm{L}-17$ & IL-6 production and HLA class I in muscle cells & {$[40,41]$} \\
\hline $\mid \mathrm{L}-15^{1}$ & T-cell activation, development of NK cells and NK-T-cells & {$[51]$} \\
\hline Type 1 interferons (IFN- $a$, IFN- $\beta$ ) & Enhance type 1 interferon inducible transcripts (ISG15, MX1, IFIT3 and IRF7) & {$[42-44]$} \\
\hline Leukotriene B4 & Chemo-attractant & {$[45]$} \\
\hline Macrophage inflammatory proteins $(1 a, 1 \beta)$ & Contribute to ongoing muscle inflammation & {$[46]$} \\
\hline RANTES $^{2}$ & Chemo-attractant & {$[46]$} \\
\hline Resistin/Adipocyte secreted factor & Pro-inflammatory, probably involved in metabolic dysregulation & {$[47-49]$} \\
\hline TWEAK ${ }^{3}$ & Impairs muscle differentiation and myogenesis & {$[50]$} \\
\hline
\end{tabular}

${ }^{1}$ IL-15 and IL-6 are also called myokines.

${ }^{2}$ RANTES: Regulated on activation, normally $T$ expressed and secreted.

${ }^{3}$ TWEAK: Tumor necrosis factor like weak inducer of apoptosis.

I-presenting peptides). The role of $\mathrm{CD} 4+$ and $\mathrm{CD} 8+$ $\mathrm{T}$-cells in inflammatory myopathies has been recognized; however, their precise roles in the pathogenesis of myositis are not completely understood. In the pathology of DM, CD4+ T-cells are thought to play a major role; in contrast, CD8+ T-cells seem to be the predominant actors in PM $[59,60]$. CD8+ T-cells infiltrating myositis muscle have been shown to express perforin-1 and granzyme-B enzymes, indicating that they have a cytotoxic effect on the affected muscle (Figure 2) [58]. Recent studies demonstrate the presence of CD28 $8^{\text {null }}$ T-cells, Th17 cells, and Tregulatory cells in the muscle of PM and DM patients $[53,56,57]$ (Figure 2). The CD28 ${ }^{\text {null }}$ T-cells arise as a result of a chronic inflammatory stimulus (such as infection from virus) and are generally long-lived and pro-inflammatory in nature. Likewise Th17 cells produce IL-17 and IL-22. IL-22 has both tissue protection and proinflammatory properties. Contribution of Th17 cells to inflammatory process in autoimmune diseases, such as rheumatoid arthritis, is well delineated. Regulatory T-cells, which express CD25, reduce inflammation and tissue damage by inhibiting the function of antigen presenting cells and T-effector cells. Even though the presence of different T-cell subpopulations in myositis muscle has been well documented, their precise role in muscle pathology is not yet clear.

\section{B-cells and autoantibodies}

B-cells that are derived from bone marrow migrate to secondary lymphoid organs to elicit antigen specific humoral immune response. B-cells and terminally differentiated plasma cells have also been reported not only in PM and DM but also in SIBM, indicating their role in the pathogenesis of these diseases [61]. More recent reports indicating an up-regulation of B-cell activating factor (BAFF) have also suggested that a local maturation of B-cells to antibody-producing plasma cells may occur in myositis muscle [61,62]. Despite the presence of lymphoid aggregates, it is highly unlikely that B-cell maturation occurs in the muscle; rather, these B-cells may serve an antigen-presenting function.

Presence of myositis-specific antibodies against autoantigens such as histidyl-tRNA synthetase (anti-Jo-1) and chromodomain-helicase DNA-binding proteins (anti-Mi-2) has been well established in myositis patients; more than half of all patients show autoantibodies. Several different autoantibodies have been reported in different myopathies [3,63-81] (Table 2). The majority of antibodies reported are directed against ubiquitous cytoplasmic or nuclear components involved in critical cellular regulatory processes and the role of autoantibodies in mediating muscle damage and injury is uncertain in myositis. However, autoantibodies are extremely useful for diagnosing and classifying myositis patients and for predicting disease course and therapeutic outcomes. For more information on myositis autoantibodies, readers are advised to consult the reviews $[82,83]$.

\section{Dendritic cells connect the innate and adaptive arms of the immune system}

There is clear evidence that innate and adaptive immune cytokines influence each other. For instance, IL-18 stimulates the secretion of IFN- $\gamma$ and TNF- $\alpha$ via a Th1mediated response $[84,85]$. Similarly, IL-1 $\beta$ binds to IL-1 receptor on dendritic cells and produces IL-23 via a Th17-mediated response, and IL-33 binds to IL-1 receptor-related protein (ST2) and enhances the secretion of IL-10 and IL-13 through Th2-mediated responses [86]. IL-33 also induces the secretion of IL-13, IL-10 and TGF- $\beta$ by stimulating mast cells and T-reg cells [86]. These interactions through cytokines highlight that innate and adaptive immune processes are interrelated 


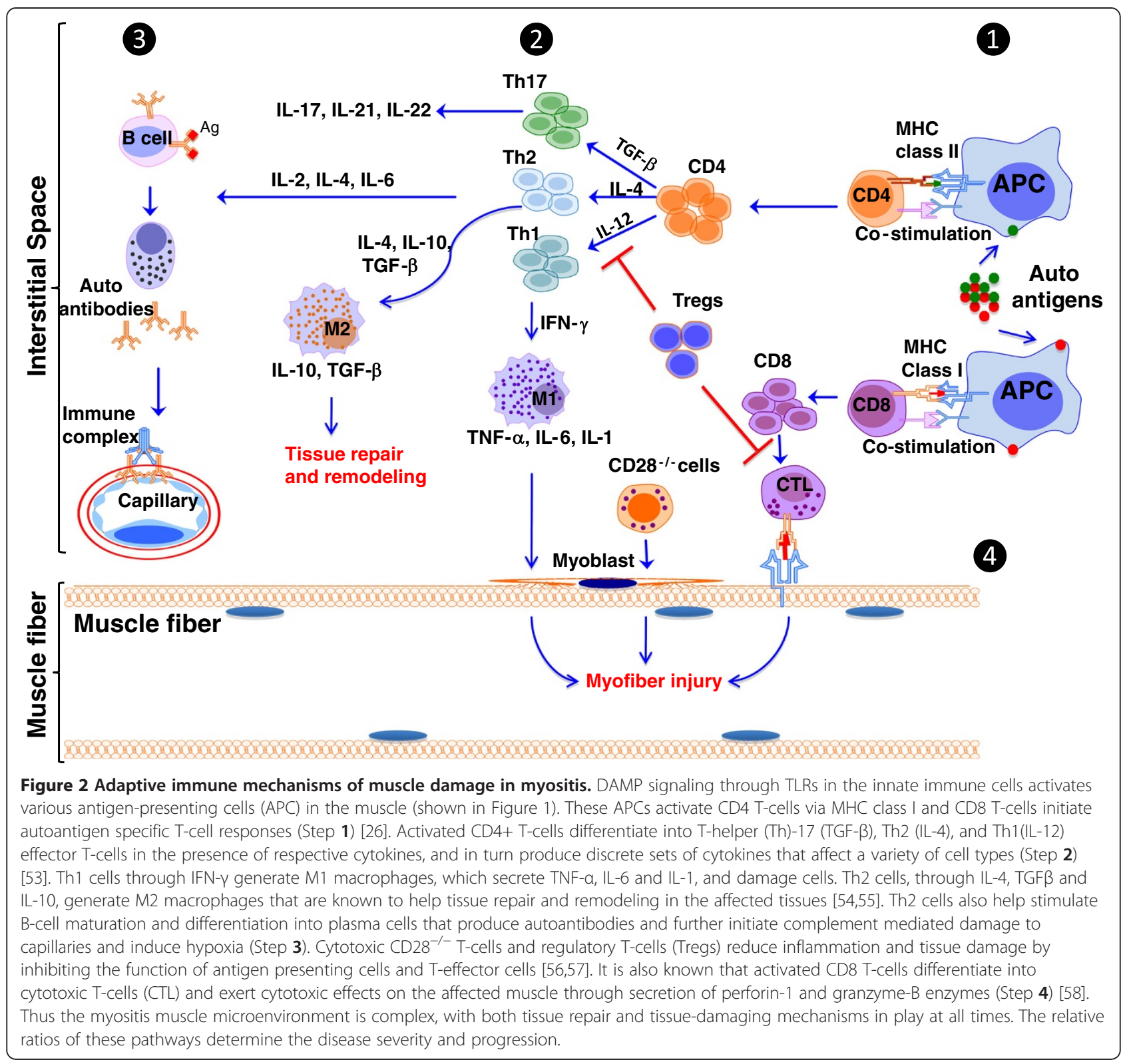

and studies to understand their role in muscle disease pathogenesis are imminent.

DCs are bone marrow-derived immune cells that connect innate and adaptive immune systems. DCs are considered professional antigen-presenting cells, and their main function is to prime and activate naïve T-lymphocytes. Immature DCs express CD1a and blood dendritic cell antigen 2 (BDCA2) surface markers, whereas mature DCs express DC-LAMP, CD83 and fascin surface markers. We have previously shown that DCLAMP-positive dendritic cells are highly enriched in perivascular inflammatory sites in juvenile and adult DM patients, along with molecules that facilitate dendritic cell transmigration and reverse transmigration (CD142 and
CD31) [87]. Both immature and mature DCs have been found to be present in DM and PM biopsies $[88,89]$. Recent studies have reported that myeloid DCs may regulate type I IFN-mediated induction of cytokines and chemokines in DM muscle, indicating an association between DCs and type I IFN signatures in myositis muscle [90]. More recently, plasmacytoid DCs (pDCs) have also been implicated in myositis pathology. pDCs are innate immune cells with a plasma-cell morphology that express CD4 or the myeloid-cell markers MHC class II, CD36, CD68 and CD123 [91]. pDCs characteristically produce type I IFNs and other chemokines in response to virusderived nucleic acids, via the activation of endosomal TLR-7 and TLR-9 pathways (Figure 1). They may serve as 
Table $\mathbf{2}$ Some of the important autoantibodies reported in inflammatory myopathies

\begin{tabular}{|c|c|c|c|}
\hline Autoantibodies & Disease & Association & References \\
\hline $\begin{array}{l}\text { Anti-tRNA synthetases }{ }^{1} \text { (Anti-Jo; against } \\
\text { histidyl tRNA synthetase) }\end{array}$ & More common in PM than DM & Interstitial lung disease & {$[63-65]$} \\
\hline $\begin{array}{l}\text { Anti-chromodomain helicase DNA binding } \\
\text { proteins (anti-Mi2) }\end{array}$ & $\mathrm{DM}$ & Cutaneous lesions & {$[3,66,67]$} \\
\hline Anti-MDA5/Anti-CADM-140 & $\mathrm{DM}$ & $\begin{array}{l}\text { Mucocutaneous lesions; severe lung disease } \\
\text { minimal muscle involvement }\end{array}$ & {$[68-70]$} \\
\hline Anti-TIF1 $\gamma^{2}$ & $\mathrm{DM}$ & Malignancy & {$[71-73]$} \\
\hline Anti-nuclear matrix protein (NXP)-2/anti-MJ & Mostly juvenile DM & Joint contractures; calcinosis & {$[74]$} \\
\hline Anti-SAE ${ }^{3}$ & DM & Skin and muscle manifestations & {$[75]$} \\
\hline Anti-signal recognition particle & NM, PM & $\begin{array}{l}\text { Degenerating and regenerating muscle fibers } \\
\text { and possible cardiac involvement }\end{array}$ & {$[76-79]$} \\
\hline Anti-HMG-CoA reductase ${ }^{4}$ & Statin associated myopathy & Treatment with cholesterol lowering drugs & {$[80,81]$} \\
\hline
\end{tabular}

PM Polymyositis, DM Dermatomyositis, NM Necrotizing myopathy.

${ }^{1}$ Additional antisynthetase antibodies found in myositis are targeted against threonyl-tRNA synthetase (PL-7); alanyl-tRNA synthetase (PL-12); isoleucyl-tRNA synthetase (OJ); glycyl-tRNA synthetase (EJ); asparaginyl-tRNA synthetase (KS).

${ }^{2}$ TIF1Y: Transcription intermediary factor $1 \gamma$.

${ }^{3} \mathrm{SAE}$ : Small ubiquitin like modifier activating enzyme.

${ }^{4} \mathrm{HMG}-\mathrm{CoA}$ reductase: 3-hydroxy-3-methylglutaryl-coenzymeA reductase.

an essential link between innate and adaptive immune mechanisms through the secretion of type 1 IFNs and other cytokines [92,93].

Macrophages are tissue-based phagocytic cells derived from peripheral monocytes. They carry out a multitude of functions, including antigen presentation to T-cells and scavenging of necrotic tissues via phagocytosis. Different types of macrophages in the muscle clearly influence the type of the adaptive immune response (e.g., Th1 or Th2). Distinct subpopulations of macrophages have been described; M1 macrophages, in association with Th1 cells, produce pro-inflammatory mediators and are involved in the phagocytosis of microorganisms and neoplastic cells. M2 macrophages are Th2-associated and are involved in tissue remodeling/repair and the production of anti-inflammatory molecules. Depending on their stage of activation, macrophages exhibit different surface markers; MIF-related protein (MRP) 14 and 27E10 represent early-stage markers; 25F9 is a lateactivation marker. Infiltration of macrophages into myositis tissues and the presence of CD163 positive (M1) macrophages are described in myositis muscle [4,54,55]. Characterization of macrophage subtypes in PM and DM muscle indicated that they express both early, MRP14 and 27E10 (M1 macrophage) and late activation 25F9 (M2 macrophage) and inflammatory markers such as iNOS and TGF- $\beta[54,55]$. These studies indicate that both M1 and M2 macrophages exist in the myositis muscle and their relative proportions may vary depending on the stage of the disease process. Therefore, interactions between innate immune cells/cytokines and lymphocytes appear to be dynamic and alter with the type and stage of the disease.

\section{Non-immune mechanisms}

Because of the presence of immune cells, it is generally thought that myofiber damage is the consequence of an immune process to muscle derived antigen. However, several observations suggest the involvement of nonimmune mechanisms in myositis pathology: 1) the lack of a correlation between the degree of inflammation and skeletal muscle weakness; 2) the lack of a response to potent immunosuppresants by some myositis patients; and 3) the lack of any amelioration of clinical disease even after complete removal of inflammatory infiltrates from the myositis muscle. Here we describe the literature related to skeletal muscle homeostasis and metabolism that supports a role for non-immune mechanisms in myositis pathology. Hereditary IBM (hIBM) is a an autosomal recessive muscle disorder tied to a mutation in the UDP-N-acetylglucosamine 2-epimerase/ $\mathrm{N}$-acetylmannosamine kinase (GNE) that codes for a rate-limiting enzyme in the sialic acid biosynthetic pathway. Pathogenesis of hIBM is considered noninflammatory and is not discussed in this review. All the information discussed in this section is summarized in Figure 3.

\section{Metabolic/energy pathways in skeletal muscle}

Mitochondrial energy-related metabolic pathways play a prominent role in skeletal muscle because of the high demand for energy in these cells. Mitochondria can regulate various signaling pathways via the production of ATP, NADH and reactive oxygen species. Emerging evidence indicates a probable dysregulation of mitochondrial energy pathways in inflammatory muscle diseases $[99,105]$. Studies have reported abnormal succinic 


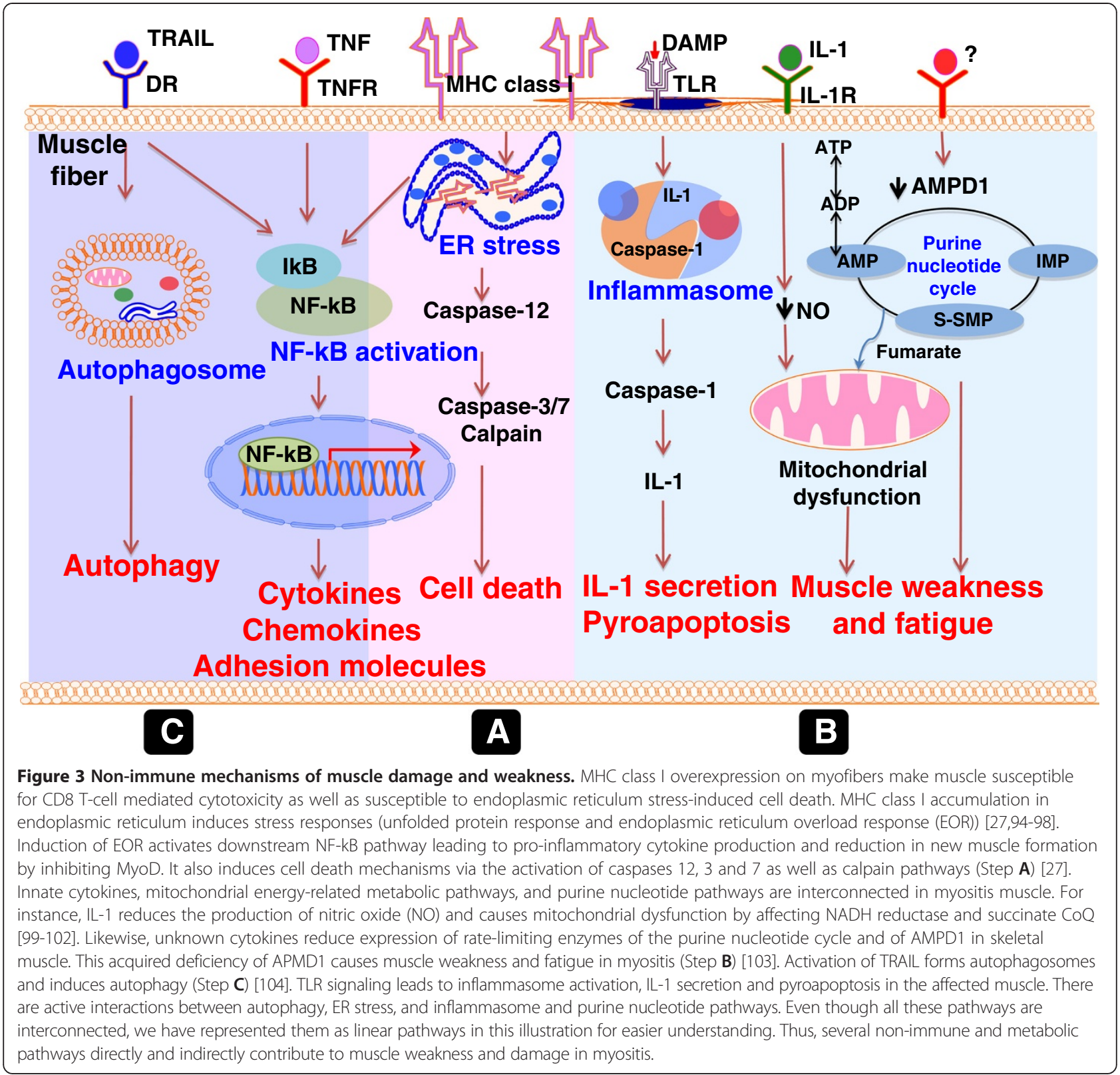

dehydrogenase and cytochrome c oxidase (COX) activities in DM muscle and observed that these abnormalities are more pronounced in damaged, atrophic perifascicular fibers $[100,101]$. Pro-inflammatory cytokines (specifically TNF- $\alpha$ ) have also been shown to affect muscle metabolism, leading to weakness. TNF- $\alpha$ acts via the TNFR1 receptor subtype and reduces the specific force generated by muscles. This reduction in force is attributed to increased cytosolic oxidant activity and decreased myofibrillar function and specific force without altering calcium regulation or other aspects of myofibrillar mechanics [102]. These findings indicate a potentially detrimental effect of proinflammatory cytokines on skeletal muscle and mitochondrial energy metabolic pathways.
One of the often-overlooked features of myositis is the apparent acquisition of metabolic defects within the skeletal muscle. These defects are generally described as deficiencies of glycolytic enzymes and other proteins found preferentially in fast-twitch fibers. One of the oldest proposed metabolic defects in inflammatory myopathies is an acquired deficiency of a rate-limiting enzyme, AMPD1, in purine nucleotide cycle $[106,107]$. Recently, our group demonstrated that AMPD1 mRNA, protein expression and enzyme activity are significantly reduced in the MHC class I mouse model of myositis, as compared to healthy littermate mice [103]. A cause-andeffect relationship between AMPD1 and muscle weakness has been demonstrated by reducing the levels of 
AMPD1 in normal mice. The most novel observation was that a significant loss of AMPD1 enzyme activity and muscle strength occurs prior to the appearance of infiltrating lymphocytes. These results suggest that the metabolic deficiencies seen in myositis are independent of the action of infiltrating autoreactive lymphocytes.

At this time, it is unclear what factors/cytokines regulate AMPD1 levels in skeletal muscle. Evaluation of the AMPD1 promoter has indicated that cytokines are likely to modulate AMPD1 expression in skeletal muscle. For example, the cytokine IL-15 has the potential to serve as a link between inflammation and muscle metabolism. IL-15 was first described as a weak ligand for the IL-2 receptor complex, and as such is capable of stimulating T-cell proliferation, among other immunomodulatory effects. Recent work has shown that IL-15 signaling affects the formation of fast-twitch fibers in mice; in the absence of the IL-15 receptor, muscle fibers appear to convert from fast-twitch to slow-twitch fibers [108]. Furthermore, strong staining for IL-15 has been detected in myoblasts but not in mature muscle fibers [51]. These results are particularly interesting, considering the previously mentioned evidence that immature fibers may become a focal point of inflammation as a result of the secretion of IL-15, and the subsequent loss of these IL-15-positive fibers might explain the observed shift toward slow-twitch fibers in myositis patients [51]. Even though the precise role of these metabolic pathways in the myofiber damage seen in myositis is not yet clear, it is possible that innate TLR pathways and proinflammatory cytokines regulate these mechanisms.

\section{Endoplasmic reticulum stress}

A non-immune role for MHC class I has been reported in myositis. Muscle-specific overexpression of MHC class I causes the myositis phenotype in mouse skeletal muscle [109]. Studies have reported an induction of endoplasmic reticulum stress as the result of an unusual up-regulation of MHC class I in myositis muscle [27,94-96]. More recently, studies to understand the role of endoplasmic reticulum stress in muscle pathology reported the expression of classical markers of endoplasmic reticulum stress (GRP78, GRP94 and calreticulin) in the affected skeletal muscle of both mice and humans $[27,97,98,110]$. A recent study has reported the presence of stress response proteins and heat shock proteins (Hsp) in IIM patients [111]. More specifically, the authors have examined the effects of chronic inflammation on the distribution of Hsp families 70 and 90 in muscle biopsies. Their results have indicated that regenerating, atrophic and vacuolated muscle fibers show an upregulation of both protein families, whereas infiltrating cells show enhanced levels of Hsp 90 family proteins. These results indicate a differential expression of stress proteins in muscle cells and immune cells. Thus, the authors suggest that chaperones play multifaceted roles in inflammatory muscle tissue. For more detail and a comprehensive discussion of the relationship between endoplasmic reticulum stress and muscle pathology, readers are referred to a recent review on this subject [112].

\section{Autophagy}

Autophagy is the lysosomal degradation of a cell's own proteins or organelles. Evidence of autophagy is often seen in PM and sIBM. Muscle biopsies from humans with sIBM and PM with mitochondrial pathology display the autophagosome marker LC3-II [99]. However, the precise role of autophagy in muscle diseases is controversial. It is likely that autophagy has both beneficial and adverse effects, depending on the cell stage and disease process involved. The in vitro inhibition of lysosomal autophagic enzymes has been reported to activate $\gamma$-secretase, which cleaves amyloid precursor protein to release the self-aggregating amyloid- $\beta$ fragment [113]. We have demonstrated that TNF-related apoptosis-inducing ligand (TRAIL) and markers of autophagy are upregulated in myositis muscle fibers. Incubation of skeletal muscle cells with TRAIL induces IKB degradation and $N F-\kappa B$ activation, suggesting that it mediates the activation of NF- $\mathrm{kB}$ as well as autophagic cell death in myopathic muscle [104]. Another recent report has also indicated that TNF- $\alpha$ induces macroautophagy and subsequent expression of MHC class II on muscle cells [114]. More importantly, blockade of TNF- $\alpha$ with monoclonal antibodies has been shown to improve $C$ protein-induced myositis (CIM) in mice, suggesting a probable role for autophagic pathways in myositis pathology [115]. In addition, immunomodulators such as fibrinogen and HMGB1 are correlated with the progression of myositis and are believed to induce autophagy by signaling through TLR-4, indicating a probable association with innate immune mechanisms [116]. Even though these findings indicate that autophagy plays a role in myofiber damage in myositis, further studies are needed to show how and when these autophagic mechanisms are triggered in the affected muscle.

\section{Conclusions}

The emerging picture indicates that myositis is a complex disease with multiple pathogenic pathways simultaneously contributing to muscle damage and weakness. Among these, the most prominent are the innate, adaptive immune and metabolic pathways. Innate immune pathways link the adaptive and metabolic arms of the disease processes. Additional new pathways and the precise interactions between these components are likely to be described in the future, and the relative contribution of each of these pathways to pathogenesis remains to be 
elucidated. However, it is clear that targeting the adaptive immune system alone is unlikely to provide significant relief from muscle weakness and damage in this group of disorders. New therapies are needed to modulate both the innate immune and metabolic components of the disease processes in order to obtain significant amelioration of the myositis phenotype.

\begin{abstract}
Abbreviations
AMPD1: Adenosine monophosphate deaminase 1; ASC: Apoptosis-associated speck-like protein with caspase recruiting domain; BDCA2: Blood dendritic cell antigen 2; CIM: C protein-induced myositis; CK: Creatine kinase; COX: Cytochrome c oxidase; DAMP: Damage-associated molecular pattern; DC: Dendritic cells; DM: Dermatomyositis; EAM: Experimental autoimmune myositis; hIBM: Hereditary inclusion body myositis; HMGB1: High mobility group box protein 1; HRS: Histidyl-tRNA-synthetase; Hsp: Heat shock protein; ICAM: Intercellular adhesion molecules; IFN: Interferon; IIM: Idiopathic inflammatory myopathy; IKK: IKB kinase; IL: Interleukin; MHC: Major histocompatibility complex; MyD88: Myeloid differentiation response gene 88; NF-kB: nuclear factor-kB; NK: natural killer; NLR: Nucleotide-binding oligomerization domain (NOD)-like receptor; PAMP: Pathogen-associated molecular pattern; PM: Polymyositis; sIBM: Sporadic Inclusion body myositis; TGF: Transforming growth factor; TLR: Toll-like receptors; TNF: Tumor necrosis factor; TRAIL: TNF-related apoptosis-inducing ligand; TRIF: Toll-interleukin receptor domain-containing adapter-inducing interferon- $\beta$.
\end{abstract}

\section{Competing interests}

The authors declare that they have no competing interests.

\section{Authors' contributions}

SR and KN were involved in drafting all sections of the manuscript and revising it critically for important intellectual content. WC and TBK were involved in writing non-immune mechanisms section. All authors read and approved the final manuscript.

\section{Acknowledgements}

Dr. Nagaraju is supported by NIH (RO1-AR050478; 5U54HD053177; K26OD011171), Muscular Dystrophy Association, and US Department of Defense (W81XWH-05-1-0616). Sree Rayavarapu is supported by a Pre-doctoral Fellowship from the Association Francaise Contreles Myopathies. Authors would like to thank Dr. Deborah McClellan for editing this manuscript.

Received: 2 January 2013 Accepted: 22 April 2013

Published: 7 June 2013

\section{References}

1. Zong M, Bruton JD, Grundtman C, Yang H, Li JH, Alexanderson H, Palmblad $K$, Andersson U, Harris HE, Lundberg IE, Westerblad H: TLR4 as receptor for HMGB1 induced muscle dysfunction in myositis. Ann Rheum Dis 2012. Epub ahead of print.

2. Coley W, Rayavarapu S, Pandey GS, Sabina RL, Van der Meulen JH, Ampong B, Wortmann RL, Rawat R, Nagaraju K: The molecular basis of skeletal muscle weakness in a mouse model of inflammatory myopathy. Arthritis Rheum 2012, 64:3750-3759.

3. Alger HM, Raben N, Pistilli E, Francia DL, Rawat R, Getnet D, Ghimbovschi S, Chen YW, Lundberg IE, Nagaraju K: The role of TRAIL in mediating autophagy in myositis skeletal muscle: a potential nonimmune mechanism of muscle damage. Arthritis Rheum 2011, 63:3448-3457.

4. Lu YC, Yeh WC, Ohashi PS: LPS/TLR4 signal transduction pathway. Cytokine 2008, 42:145-151.

5. Grundtman C, Bruton J, Yamada T, Ostberg T, Pisetsky DS, Harris HE, Andersson U, Lundberg IE, Westerblad H: Effects of HMGB1 on in vitro responses of isolated muscle fibers and functional aspects in skeletal muscles of idiopathic inflammatory myopathies. FASEB J 2010, 24:570-578.

6. Ulfgren AK, Grundtman C, Borg K, Alexanderson H, Andersson U, Harris $H E$, Lundberg IE: Down-regulation of the aberrant expression of the inflammation mediator high mobility group box chromosomal protein 1 in muscle tissue of patients with polymyositis and dermatomyositis treated with corticosteroids. Arthritis Rheum 2004, 50:1586-1594.

7. Schreiner B, Voss J, Wischhusen J, Dombrowski Y, Steinle A, Lochmüller H, Dalakas M, Melms A, Wiendl H: Expression of toll-like receptors by human muscle cells in vitro and in vivo: TLR3 is highly expressed in inflammatory and HIV myopathies, mediates IL-8 release and up-regulation of NKG2Dligands. FASEB J 2006, 20:118-120.

8. Kim GT, Cho ML, Park YE, Yoo WH, Kim JH, Oh HJ, Kim DS, Baek SH, Lee SH, Lee JH, Kim HY, Kim Sl: Expression of TLR2, TLR4, and TLR9 in dermatomyositis and polymyositis. Clin Rheumatol 2010, 29:273-279.

9. Tournadre A, Lenief V, Miossec P: Expression of Toll-like receptor 3 and Toll-like receptor 7 in muscle is characteristic of inflammatory myopathy and is differentially regulated by Th1 and Th17 cytokines. Arthritis Rheum 2010, 62:2144-2151.

10. Brunn A, Zornbach K, Hans VH, Haupt WF, Deckert M: Toll-like receptors promote inflammation in idiopathic inflammatory myopathies. J Neuropathol Exp Neurol 2012, 71:855-867.

11. Wang H, Hertlein E, Bakkar N, Sun H, Acharyya S, Wang J, Carathers M, Davuluri R, Guttridge DC: NF-kappaB regulation of YY1 inhibits skeletal myogenesis through transcriptional silencing of myofibrillar genes. Mol Cell Biol 2007, 27:4374-4387.

12. Bakkar N, Wang J, Ladner KJ, Wang H, Dahlman JM, Carathers M, Acharyya S, Rudnicki MA, Hollenbach AD, Guttridge DC: IKK/NF-kappaB regulates skeletal myogenesis via a signaling switch to inhibit differentiation and promote mitochondrial biogenesis. J Cell Biol 2008, 180:787-802.

13. Creus KK, De Paepe B, Werbrouck BF, Vervaet V, Weis J, De Bleecker JL: Distribution of the NF-kappaB complex in the inflammatory exudates characterizing the idiopathic inflammatory myopathies. Ann N Y Acad Sci 2009, 1173:370-377.

14. Lu YC, Kim I, Lye E, Shen F, Suzuki N, Gerondakis S, Akira S, Gaffen SL, Yeh WC, Ohashi PS: Differential role for c-Rel and C/EBPbeta/delta in TLR-mediated induction of proinflammatory cytokines. J Immunol 2009, 182:7212-7221.

15. Medzhitov R, Preston-Hurlburt P, Janeway CA Jr: A human homologue of the Drosophila Toll protein signals activation of adaptive immunity. Nature 1997, 388:394-397.

16. Rock FL, Hardiman G, Timans JC, Kastelein RA, Bazan JF: A family of human receptors structurally related to Drosophila Toll. Proc Natl Acad Sci USA 1998, 95:588-593.

17. Park JS, Gamboni-Robertson F, He Q, Svetkauskaite D, Kim JY, Strassheim D, Sohn JW, Yamada S, Maruyama I, Banerjee A, Ishizaka A, Abraham E: High mobility group box 1 protein interacts with multiple Toll-like receptors. Am J Physiol Cell Physiol 2006, 290:C917-C924.

18. Zhang P, Cox CJ, Alvarez KM, Cunningham MW: Cutting edge: cardiac myosin activates innate immune responses through TLRs. I Immunol 2009, 183:27-31.

19. Foell D, Wittkowski H, Roth J: Mechanisms of disease: a 'DAMP' view of inflammatory arthritis. Nat Clin Pract Rheumatol 2007, 3:382-390.

20. Foell D, Wittkowski $H$, Vogl T, Roth J: S100 proteins expressed in phagocytes: a novel group of damage-associated molecular pattern molecules. J Leukoc Biol 2007, 81:28-37.

21. Ionita MG, Arslan F, de Kleijn DP, Pasterkamp G: Endogenous inflammatory molecules engage Toll-like receptors in cardiovascular disease. J Innate Immun 2010, 2:307-315.

22. Tournadre A, Lenief $\mathrm{V}$, Eljaafari A, Miossec P: Immature muscle precursors are a source of interferon-beta in myositis: role of Toll-like receptor 3 activation and contribution to HLA class I up-regulation. Arthritis Rheum 2012, 64:533-541.

23. Zhang HY, Kang J, Han WJ, Hu MM, Jia HG: The expression and significance of TLR4, MyD88 and NF-kappaB mRNA in mouse lymph node of experimental autoimmune myositis. Xi Bao Yu Fen Zi Mian Yi Xue Za Zhi 2012, 28:272-275.

24. Howard OM, Dong HF, Yang D, Raben N, Nagaraju K, Rosen A, Casciola-Rosen L, Härtlein M, Kron M, Yang D, Yiadom K, Dwivedi S, Plotz PH, Oppenheim JJ: Histidyl-tRNA synthetase and asparaginyl-tRNA synthetase, autoantigens in myositis, activate chemokine receptors on $\mathrm{T}$ lymphocytes and immature dendritic cells. J Exp Med 2002, 196:781-791.

25. Harlow L, Fernandez I, Soejima M, Ridgway WM, Ascherman DP: Characterization of TLR4-mediated auto-antibody production in a mouse model of histidyl-tRNA synthetase-induced myositis. Innate Immun 2012, 18:876-885 
26. Casciola-Rosen L, Nagaraju K, Plotz P, Wang K, Levine S, Gabrielson E, Corse $A$, Rosen $A$ : Enhanced autoantigen expression in regenerating muscle cells in idiopathic inflammatory myopathy. J Exp Med 2005, 201:591-601.

27. Nagaraju K, Casciola-Rosen L, Lundberg I, Rawat R, Cutting S, Thapliyal R, Chang J, Dwivedi S, Mitsak M, Chen YW, Plotz P, Rosen A, Hoffman E, Raben $\mathrm{N}$ : Activation of the endoplasmic reticulum stress response in autoimmune myositis: potential role in muscle fiber damage and dysfunction. Arthritis Rheum 2005, 52:1824-1835.

28. Monici MC, Aguennouz M, Mazzeo A, Messina C, Vita G: Activation of nuclear factor-kappaB in inflammatory myopathies and Duchenne muscular dystrophy. Neurology 2003, 60:993-997.

29. Mariathasan S, Weiss DS, Newton K, McBride J, O'Rourke K, Roose-Girma M, Lee WP, Weinrauch Y, Monack DM, Dixit VM: Cryopyrin activates the inflammasome in response to toxins and ATP. Nature 2006, 440:228-232.

30. Yamasaki K, Muto J, Taylor KR, Cogen AL, Audish D, Bertin J, Grant EP, Coyle AJ, Misaghi A, Hoffman HM, Gallo RL: NLRP3/cryopyrin is necessary for interleukin-1 beta (IL-1 beta) release in response to hyaluronan, an endogenous trigger of inflammation in response to injury. J Biol Chem 2009, 284:12762-12771.

31. Bryant C, Fitzgerald KA: Molecular mechanisms involved in inflammasome activation. Trends Cell Biol 2009, 19:455-464.

32. Rawat R, Cohen TV, Ampong B, Francia D, Henriques-Pons A, Hoffman EP, Nagaraju K: Inflammasome up-regulation and activation in dysferlindeficient skeletal muscle. Am J Pathol 2010, 176:2891-2900.

33. Segovia J, Sabbah A, Mgbemena V, Tsai SY, Chang TH, Berton MT, Morris IR, Allen IC, Ting JPY, Bose S: TLR2/MyD88/NF-kappaB pathway, reactive oxygen species, potassium efflux activates NLRP3/ASC inflammasome during respiratory syncytial virus infection. PLoS One 2012, 7:e29695.

34. Lundberg I, Ulfgren AK, Nyberg P, Andersson U, Klareskog L: Cytokine production in muscle tissue of patients with idiopathic inflammatory myopathies. Arthritis Rheum 1997, 40:865-874.

35. Lundberg I, Brengman JM, Engel AG: Analysis of cytokine expression in muscle in inflammatory myopathies, Duchenne dystrophy, and nonweak controls. J Neuroimmunol 1995, 63:9-16.

36. Authier FJ, Mhiri C, Chazaud B, Christov C, Cherin P, Barlovatz-Meimon G, Gherardi RK: Interleukin-1 expression in inflammatory myopathies: evidence of marked immunoreactivity in sarcoid granulomas and muscle fibres showing ischaemic and regenerative changes. Neuropathol Appl Neurobiol 1997, 23:132-140.

37. De Bleecker JL, Meire VI, Declercq W, Van Aken EH: Immunolocalization of tumor necrosis factor-alpha and its receptors in inflammatory myopathies. Neuromuscul Disord 1999, 9:239-246.

38. Tateyama M, Nagano I, Yoshioka M, Chida K, Nakamura S, Itoyama Y: Expression of tumor necrosis factor-alpha in muscles of polymyositis. J Neurol Sci 1997, 146:45-51.

39. Confalonieri P, Bernasconi P, Cornelio F, Mantegazza R: Transforming growth factor-beta 1 in polymyositis and dermatomyositis correlates with fibrosis but not with mononuclear cell infiltrate. J Neuropathol Exp Neurol 1997, 56:479-484.

40. Chevrel G, Granet C, Miossec P: Contribution of tumour necrosis factor alpha and interleukin (IL) 1beta to IL6 production, NF-kappaB nuclear translocation, and class I MHC expression in muscle cells: in vitro regulation with specific cytokine inhibitors. Ann Rheum Dis 2005, 64:1257-1262

41. Tournadre A, Porcherot M, Cherin P, Marie I, Hachulla E, Miossec P: Th1 and Th17 balance in inflammatory myopathies: interaction with dendritic cells and possible link with response to high-dose immunoglobulins. Cytokine 2009, 46:297-301.

42. Cappelletti C, Baggi F, Zolezzi F, Biancolini D, Beretta O, Severa M, Coccia EM, Confalonieri P, Morandi L, Mora M, Mantegazza R, Bernasconi P: Type I interferon and Toll-like receptor expression characterizes inflammatory myopathies. Neurology 2011, 76:2079-2088.

43. Eloranta ML, Barbasso Helmers S, Ulfgren AK, Ronnblom L, Alm GV, Lundberg IE: A possible mechanism for endogenous activation of the type I interferon system in myositis patients with anti-Jo-1 or anti-Ro 52/anti-Ro 60 autoantibodies. Arthritis Rheum 2007, 56:3112-3124.

44. Greenberg SA, Higgs BW, Morehouse C, Walsh RJ, Kong SW, Brohawn P, Zhu W, Amato A, Salajegheh M, White B, Kiener PA, Jallal B, Yao Y: Relationship between disease activity and type 1 interferon- and other cytokine-inducible gene expression in blood in dermatomyositis and polymyositis. Genes Immun 2012, 13:207-213.

45. Loell I, Alemo Munters L, Pandya J, Zong M, Alexanderson H, Fasth AE, Hallengren CS, Rådmark O, Lundberg IE, Jakobsson PJ, Korotkova M: Activated LTB4 pathway in muscle tissue of patients with polymyositis or dermatomyositis. Ann Rheum Dis 2012, 72:293-299.

46. Adams EM, Kirkley J, Eidelman G, Dohlman J, Plotz PH: The predominance of beta (CC) chemokine transcripts in idiopathic inflammatory muscle diseases. Proc Assoc Am Physicians 1997, 109:275-285.

47. Filkova M, Hulejova H, Kuncova K, Plestilova L, Cerezo LA, Mann H, Klein M, Zámečník J, Gay S, Vencovský J, Senolt L: Resistin in idiopathic inflammatory myopathies. Arthritis Res Ther 2012, 14:R111.

48. Filkova M, Haluzik M, Gay S, Senolt L: The role of resistin as a regulator of inflammation: Implications for various human pathologies. Clin Immunol 2009, 133:157-170

49. Bokarewa M, Nagaev I, Dahlberg L, Smith U, Tarkowski A: Resistin, an adipokine with potent proinflammatory properties. J Immunol 2005, 174:5789-5795.

50. Morosetti R, Gliubizzi C, Sancricca C, Broccolini A, Gidaro T, Lucchini M, Mirabella M: TWEAK in inclusion-body myositis muscle: possible pathogenic role of a cytokine inhibiting myogenesis. Am J Pathol 2012, 180:1603-1613.

51. Zong M, Loell I, Lindroos E, Nader GA, Alexanderson H, Hallengren CS, Borg K Arnardottir S, McInnes IB, Lundberg IE: Effects of immunosuppressive treatment on interleukin-15 and interleukin-15 receptor alpha expression in muscle tissue of patients with polymyositis or dermatomyositis. Ann Rheum Dis 2012, 71:1055-1063.

52. Colombo E, Romaggi S, Blasevich F, Mora M, Falcone C, Lochmüller H, Morandi L, Farina C: The neurotrophin receptor p75NTR is induced on mature myofibres in inflammatory myopathies and promotes myotube survival to inflammatory stress. Neuropathol Appl Neurobiol 2012, 38:367-378

53. Bettelli E, Oukka M, Kuchroo VK: $T(H)-17$ cells in the circle of immunity and autoimmunity. Nat Immunol 2007, 8:345-350.

54. Rostasy KM, Piepkorn M, Goebel HH, Menck S, Hanefeld F, Schulz-Schaeffer WJ: Monocyte/macrophage differentiation in dermatomyositis and polymyositis. Muscle Nerve 2004, 30:225-230.

55. Rostasy KM, Schmidt J, Bahn E, Pfander T, Piepkorn M, Wilichowski E, Schulz-Schaeffer J: Distinct inflammatory properties of late-activated macrophages in inflammatory myopathies. Acta Myol 2008, 27:49-53.

56. Fasth AE, Dastmalchi M, Rahbar A, Salomonsson S, Pandya JM, Lindroos E, Nennesmo I, Malmberg KJ, Söderberg-Nauclér C, Trollmo C, Lundberg IE, Malmström $\mathrm{V}$ : T-cell infiltrates in the muscles of patients with dermatomyositis and polymyositis are dominated by CD28null T-cells. J Immunol 2009, 183:4792-4799.

57. Waschbisch A, Schwab N, Ruck T, Stenner MP, Wiendl H: FOXP3+ T regulatory cells in idiopathic inflammatory myopathies. J Neuroimmunol 2010, 225:137-142

58. Goebels N, Michaelis D, Engelhardt M, Huber S, Bender A, Pongratz D, Johnson MA, Wekerle H, Tschopp J, Jenne D, Hohlfeld R: Differential expression of perforin in muscle-infiltrating T-cells in polymyositis and dermatomyositis. J Clin Invest 1996, 97:2905-2910.

59. Arahata K, Engel AG: Monoclonal antibody analysis of mononuclear cells in myopathies. I: Quantitation of subsets according to diagnosis and sites of accumulation and demonstration and counts of muscle fibers invaded by T-cells. Ann Neurol 1984, 16:193-208.

60. Arahata K, Engel AG: Monoclonal antibody analysis of mononuclear cells in myopathies. III: Immunoelectron microscopy aspects of cell-mediated muscle fiber injury. Ann Neurol 1986, 19:112-125.

61. Greenberg SA, Bradshaw EM, Pinkus JL, Pinkus GS, Burleson T, Due B, Bregoli L, O'Connor KC, Amato AA: Plasma cells in muscle in inclusion body myositis and polymyositis. Neurology 2005, 65:1782-1787.

62. Salajegheh M, Pinkus JL, Amato AA, Morehouse C, Jallal B, Yao Y, Greenberg SA: Permissive environment for B-cell maturation in myositis muscle in the absence of B-cell follicles. Muscle Nerve 2010, 42:576-583

63. Nishikai M, Reichlin M: Heterogeneity of precipitating antibodies in polymyositis and dermatomyositis. Characterization of the Jo- 1 antibody system. Arthritis Rheum 1980, 23:881-888.

64. Yoshida S, Akizuki M, Mimori T, Yamagata H, Inada S, Homma M: The precipitating antibody to an acidic nuclear protein antigen, the Jo-1, in connective tissue diseases. A marker for a subset of polymyositis with 
interstitial pulmonary fibrosis. Arthritis Rheum 1983, 26:604-611.

65. Stone KB, Oddis CV, Fertig N, Katsumata Y, Lucas M, Vogt M, Domsic R, Ascherman DP: Anti-Jo-1 antibody levels correlate with disease activity in idiopathic inflammatory myopathy. Arthritis Rheum 2007, 56:3125-3131.

66. Reichlin M, Mattioli M: Description of a serological reaction characteristic of polymyositis. Clin Immunol Immunopathol 1976, 5:12-20.

67. Targoff IN, Reichlin M: The association between Mi-2 antibodies and dermatomyositis. Arthritis Rheum 1985, 28:796-803.

68. Sato S, Hirakata M, Kuwana M, Suwa A, Inada S, Mimori T, Nishikawa T, Oddis CV, Ikeda Y: Autoantibodies to a 140-kd polypeptide, CADM-140, in Japanese patients with clinically amyopathic dermatomyositis. Arthritis Rheum 2005, 52:1571-1576.

69. Nakashima R, Imura Y, Kobayashi S, Yukawa N, Yoshifuji H, Nojima T, Kawabata D, Ohmura K, Usui T, Fujii T, Okawa K, Mimori T: The RIG-I-like receptor IFIH1/ MDA5 is a dermatomyositis-specific autoantigen identified by the antiCADM-140 antibody. Rheumatology (Oxford) 2010, 49:433-440.

70. Chaisson NF, Paik J, Orbai AM, Casciola-Rosen L, Fiorentino D, Danoff S, Rosen A: A novel dermato-pulmonary syndrome associated with MDA-5 antibodies: report of 2 cases and review of the literature. Medicine (Baltimore) 2012, 91:220-228.

71. Targoff IN, Mamyrova G, Trieu EP, Perurena O, Koneru B, O'Hanlon TP, Miller FW, Rider LG, Childhood Myositis Heterogeneity Study Group; International Myositis Collaborative Study Group: A novel autoantibody to a $155-\mathrm{kd}$ protein is associated with dermatomyositis. Arthritis Rheum 2006, 54:3682-3689.

72. Kaji K, Fujimoto M, Hasegawa M, Kondo M, Saito Y, Komura K, Matsushita T, Orito H, Hamaguchi Y, Yanaba K, Itoh M, Asano Y, Seishima M, Ogawa F, Sato S, Takehara K: Identification of a novel autoantibody reactive with 155 and $140 \mathrm{kDa}$ nuclear proteins in patients with dermatomyositis: an association with malignancy. Rheumatology (Oxford) 2007, 46:25-28.

73. Fujimoto M, Hamaguchi $Y$, Kaji K, Matsushita T, Ichimura Y, Kodera M, Ishiguro N, Ueda-Hayakawa I, Asano Y, Ogawa F, Fujikawa K, Miyagi T, Mabuchi E, Hirose K, Akimoto N, Hatta N, Tsutsui K, Higashi A, Igarashi A, Seishima M, Hasegawa M, Takehara K: Myositis-specific anti-155/140 autoantibodies target transcription intermediary factor 1 family proteins. Arthritis Rheum 2012, 64:513-522.

74. Gunawardena $H$, Wedderburn LR, Chinoy H, Betteridge ZE, North J, Ollier WE, Cooper RG, Oddis CV, Ramanan AV, Davidson JE, McHugh NJ, Juvenile Dermatomyositis Research Group, UK and Ireland: Autoantibodies to a $140-k d$ protein in juvenile dermatomyositis are associated with calcinosis. Arthritis Rheum 2009, 60:1807-1814

75. Tarricone E, Ghirardello A, Rampudda M, Bassi N, Punzi L, Doria A: Anti-SAE antibodies in autoimmune myositis: identification by unlabelled protein immunoprecipitation in an Italian patient cohort. J Immunol Methods 2012, 384:128-134

76. Reeves WH, Nigam SK, Blobel G: Human autoantibodies reactive with the signal-recognition particle. Proc Natl Acad Sci USA 1986, 83:9507-9511.

77. Targoff IN, Johnson AE, Miller FW: Antibody to signal recognition particle in polymyositis. Arthritis Rheum 1990, 33:1361-1370.

78. Hengstman GJ, ter Laak HJ, Vree Egberts WT, Lundberg IE, Moutsopoulos HM, Vencovsky J, Doria A, Mosca M, van Venrooij WJ, van Engelen BG: Anti-signal recognition particle autoantibodies: marker of a necrotising myopathy. Ann Rheum Dis 2006, 65:1635-1638.

79. Benveniste $\mathrm{O}$, Drouot L, Jouen F, Charuel JL, Bloch-Queyrat C, Behin A, Amoura Z, Marie I, Guiguet M, Eymard B, Gilbert D, Tron F, Herson S, Musset $L$, Boyer O: Correlation of anti-signal recognition particle autoantibody levels with creatine kinase activity in patients with necrotizing myopathy. Arthritis Rheum 2011, 63:1961-1971.

80. Christopher-Stine L, Casciola-Rosen LA, Hong G, Chung T, Corse AM, Mammen AL: A novel autoantibody recognizing 200-kd and 100-kd proteins is associated with an immune-mediated necrotizing myopathy. Arthritis Rheum 2010, 62:2757-2766

81. Mammen AL, Chung T, Christopher-Stine L, Rosen P, Rosen A, Doering KR, Casciola-Rosen LA: Autoantibodies against 3-hydroxy-3-methylglutarylcoenzyme $A$ reductase in patients with statin-associated autoimmune myopathy. Arthritis Rheum 2011, 63:713-721.

82. Casciola-Rosen L, Mammen AL: Myositis autoantibodies. Curr Opin Rheumatol 2012, 24:602-608.

83. Mammen AL: Dermatomyositis and polymyositis: Clinical presentation, autoantibodies, and pathogenesis. Ann N Y Acad Sci 2010, 1184:134-153.

84. Yoshimoto T, Takeda K, Tanaka T, Ohkusu K, Kashiwamura S, Okamura H, Akira S, Nakanishi K: IL-12 up-regulates IL-18 receptor expression on
T-cells, Th1 cells, and B cells: synergism with IL-18 for IFN-gamma production. J Immunol 1998, 161:3400-3407.

85. Smeltz RB, Chen J, Ehrhardt R, Shevach EM: Role of IFN-gamma in Th1 differentiation: IFN-gamma regulates IL-18R alpha expression by preventing the negative effects of IL- 4 and by inducing/maintaining IL-12 receptor beta 2 expression. J Immunol 2002, 168:6165-6172.

86. Schmitz J, Owyang A, Oldham E, Song Y, Murphy E, McClanahan TK, Zurawski G, Moshrefi M, Qin J, Li X, Gorman DM, Bazan JF, Kastelein RA: IL-33, an interleukin-1-like cytokine that signals via the IL-1 receptorrelated protein ST2 and induces T helper type 2-associated cytokines. Immunity 2005, 23:479-490.

87. Nagaraju K, Rider LG, Fan C, Chen YW, Mitsak M, Rawat R, Patterson K, Grundtman C, Miller FW, Plotz PH, Hoffman E, Lundberg IE: Endothelial cell activation and neovascularization are prominent in dermatomyositis. J Autoimmune Dis 2006, 3:2.

88. Page $G$, Chevrel $G$, Miossec P: Anatomic localization of immature and mature dendritic cell subsets in dermatomyositis and polymyositis: Interaction with chemokines and Th1 cytokine-producing cells. Arthritis Rheum 2004, 50:199-208.

89. Gendek-Kubiak H, Gendek EG: Fascin-expressing Dendritic Cells Dominate in Polymyositis and Dermatomyositis. J Rheumatol 2012, 40:186-191.

90. Maddur MS, Vani J, Lacroix-Desmazes S, Kaveri SV, Bayry J: Contribution of myeloid dendritic cells to type I interferon-induced cytokines and chemokines: comment on the article by Bilgic et al. Arthritis Rheum 2010, 62:2181-2182. Author reply 2182.

91. Facchetti $F$, Vergoni $F$ : The plasmacytoid monocyte: from morphology to function. Adv Clin Path 2000, 4:187-190

92. Kadowaki N, Antonenko S, Liu YJ: Distinct CpG DNA and polyinosinicpolycytidylic acid double-stranded RNA, respectively, stimulate CD11ctype 2 dendritic cell precursors and CD11C + dendritic cells to produce type I IFN. J Immunol 2001, 166:2291-2295.

93. Cervantes-Barragan L, Lewis KL, Firner S, Thiel V, Huques S, Reith W, Ludewig B, Reizis B: Plasmacytoid dendritic cells control T-cell response to chronic viral infection. Proc Natl Acad Sci USA 2012, 109:3012-3017.

94. Nogalska A, Engel WK, McFerrin J, Kokame K, Komano H, Askanas V: Homocysteine-induced endoplasmic reticulum protein (Herp) is up-regulated in sporadic inclusion-body myositis and in endoplasmic reticulum stressinduced cultured human muscle fibers. J Neurochem 2006, 96:1491-1499.

95. Nogalska A, Wojcik S, Engel WK, McFerrin J, Askanas V: Endoplasmic reticulum stress induces myostatin precursor protein and NF-kappaB in cultured human muscle fibers: relevance to inclusion body myositis. Exp Neurol 2007, 204:610-618.

96. Li CK, Knopp P, Moncrieffe H, Singh B, Shah S, Nagaraju K, Varsani H, Gao B Wedderburn LR: Overexpression of MHC class I heavy chain protein in young skeletal muscle leads to severe myositis. Implications for juvenile myositis. Am J Pathol 2009, 175:1030-1040.

97. Vitadello M, Doria A, Tarricone E, Ghirardello A, Gorza L: Myofiber stressresponse in myositis: parallel investigations on patients and experimental animal models of muscle regeneration and systemic inflammation. Arthritis Res Ther 2010, 12:R52.

98. Vattemi G, Engel WK, McFerrin J, Askanas V: Endoplasmic reticulum stress and unfolded protein response in inclusion body myositis muscle. Am J Pathol 2004, 164:1-7.

99. Temiz P, Weihl CC, Pestronk A: Inflammatory myopathies with mitochondrial pathology and protein aggregates. J Neurol Sci 2009, 278:25-29.

100. Miro O, Casademont J, Grau JM, Jarreta D, Urbano-Marquez A, Cardellach F: Histological and biochemical assessment of mitochondrial function in dermatomyositis. Br J Rheumatol 1998, 37:1047-1053.

101. Alhatou MI, Sladky JT, Bagasra O, Glass JD: Mitochondrial abnormalities in dermatomyositis: characteristic pattern of neuropathology. J Mol Histol 2004, 35:615-619.

102. Hardin BJ, Campbell KS, Smith JD, Arbogast S, Smith J, Moylan JS, Reid MB: TNF-alpha acts via TNFR1 and muscle-derived oxidants to depress myofibrillar force in murine skeletal muscle. J Appl Physiol 2008, 104:694-699.

103. Yamamoto M, Sato S, Mori K, Hoshino K, Takeuchi O, Takeda K, Akira S: Cutting edge: a novel Toll/IL-1 receptor domain-containing adapter that preferentially activates the IFN-beta promoter in the Toll-like receptor signaling. J Immunol 2002, 169:6668-6672.

104. Roux S, Seelig HP, Meyer O: Significance of Mi-2 autoantibodies in polymyositis and dermatomyositis. J Rheumatol 1998, 25:395-396. 
105. Schroder JM, Molnar M: Mitochondrial abnormalities and peripheral neuropathy in inflammatory myopathy, especially inclusion body myositis. Mol Cell Biochem 1997, 174:277-281.

106. Fishbein WN: Myoadenylate deaminase deficiency: inherited and acquired forms. Biochem Med 1985, 33:158-169.

107. Sabina RL, Swain JL, Olanow CW, Bradley WG, Fishbein WN, DiMauro S, Holmes EW: Myoadenylate deaminase deficiency. Functional and metabolic abnormalities associated with disruption of the purine nucleotide cycle. J Clin Invest 1984, 73:720-730.

108. Pistilli EE, Guo G, Stauber WT: IL-15Ralpha deficiency leads to mitochondrial and myofiber differences in fast mouse muscles. Cytokine 2012, 61:41-45.

109. Nagaraju K, Raben N, Loeffler L, Parker T, Rochon PJ, Lee E, Danning C, Wada R, Thompson C, Bahtiyar G, Craft J, Hooft Van Huijsduijnen R, Plotz P: Conditional up-regulation of MHC class I in skeletal muscle leads to self-sustaining autoimmune myositis and myositis-specific autoantibodies. Proc Natl Acad Sci U S A 2000, 97:9209-9214.

110. Askanas V, Engel WK: Sporadic inclusion-body myositis: conformational multifactorial ageing-related degenerative muscle disease associated with proteasomal and lysosomal inhibition, endoplasmic reticulum stress, and accumulation of amyloid-beta42 oligomers and phosphorylated tau. Presse Med 2011, 40:e219-e235.

111. Paepe BD, Creus KK, Weis J, Bleecker JL: Heat shock protein families 70 and 90 in Duchenne muscular dystrophy and inflammatory myopathy: balancing muscle protection and destruction. Neuromuscul Disord 2012, 22:26-33.

112. Rayavarapu S, Coley W, Nagaraju K: Endoplasmic reticulum stress in skeletal muscle homeostasis and disease. Curr Rheumatol Rep 2012, 14:238-243.

113. Nogalska A, D'Agostino C, Engel WK, Askanas V: Activation of the gammasecretase complex and presence of gamma-secretase-activating protein may contribute to Abeta42 production in sporadic inclusion-body myositis muscle fibers. Neurobiol Dis 2012, 48:141-149.

114. Keller CW, Fokken C, Turville SG, Lünemann A, Schmidt J, Münz C, Lünemann JD: TNF-alpha induces macroautophagy and regulates MHC class II expression in human skeletal muscle cells. J Biol Chem 2011, 286:3970-3980.

115. Sugihara T, Okiyama N, Watanabe N, Miyasaka N, Kohsaka H: Interleukin-1 and tumor necrosis factor alpha blockade treatment of experimental polymyositis in mice. Arthritis Rheum 2012, 64:2655-2662.

116. Doyle A, Zhang G, Abdel Fattah EA, Eissa NT, Li YP: Toll-like receptor 4 mediates lipopolysaccharide-induced muscle catabolism via coordinate activation of ubiquitin-proteasome and autophagy-lysosome pathways. FASEB J 2011, 25:99-110.

doi:10.1186/2044-5040-3-13

Cite this article as: Rayavarapu et al:: Idiopathic inflammatory myopathies: pathogenic mechanisms of muscle weakness. Skeletal Muscle 2013 3:13

\section{Submit your next manuscript to BioMed Central and take full advantage of:}

- Convenient online submission

- Thorough peer review

- No space constraints or color figure charges

- Immediate publication on acceptance

- Inclusion in PubMed, CAS, Scopus and Google Scholar

- Research which is freely available for redistribution 